Shinta Puspitasari | East China Sea Dispute: Paving Japan's Way to be a Stronger Nations

\title{
East China Sea Dispute: Paving Japan's Way to be a Stronger Nations
}

Shinta Puspitasari ${ }^{1}$

shinta.puspitasari0009@gmail.com

\begin{abstract}
Dispute over East China Sea between two big countries in East Asia, namely China and Japan is not something new. This dispute existed since 1968 which based on historical and territorial issue. However, China and Japan dispute over this area is never been dangerous as it is now: they both use military. Both of them have tried to make an agreement over this issue; yet, it never succeeded. Thus, Japanese policymakers now think about their border. As a result, they change their defence policy to be more aggressive. This is to say, there is a change in Japan's Self-Defence Force as well as Japan's security policy. This move may seem as abandonement of Article 9 Showa Constitution that prohibit them to have military, and has been Japanese base in their defence policy. However, Japan Prime Minister think that this bold move is needed in addition to their stronger relationship with the US.
\end{abstract}

Keywords: Japan, China, East China Sea dispute, defence policy

${ }^{1}$ Post graduate student at Flinders University 


\section{Shinta Puspitasari | East China Sea Dispute: Paving Japan's Way to be a Stronger Nations}

In 1968, the United Nations Economic Commission for Asia and Far East announced that East China Sea (Senkaku/Diaoyu) contains oil and natural resources. $^{1}$ Since then, countries surrounding that area, namely China, Japan, and Taiwan claimed the East China Sea. Competition between these countries are fierce, but compare to Japan-China dispute, dispute with Taiwan over East China Sea is quite benign. This is because Taiwan is enjoying its friendship with both giant countries in the region, which are China and Japan. Whereas, for China and Japan, East China Sea is not merely about sovereignty matter: it involves historical matter as well. As a consequence, dispute over Senkaku/Diaoyu always becomes a highlight in their relationship; this issue is even possible to bring their relationship to the worst scenario, namely military conflict.Inded, there has been many agreements between these countries about Senkaku/Diaoyu, but those agreements seem unhelpful for this problem always appears between Japan and China. More recently, in addition, situation in that area becomes more dangerous as China becomes more aggressive with its navy that makes Japan rethinks and changes its defence policy.

\footnotetext{
${ }^{1}$ Lalima Varma, 'Japan-China Relations: Problems and Prospects in the 21st Century', China Report, vol. 29 , no. 4,1993 , p. 440.
}

This essay will discuss the impact of rising tension between China and Japan in East China Sea to Japan's defence policy. Therefore, this essay will be divided into three sections. The first section will discuss the historical issue and problems that rose in East China Sea between Japan and China since 2010. The second section will discuss the historical issue in Japan's defence policy before 2009, including Japan's defence policy guidelines in 1995 and 2004. The third section will discuss about changing in Japan's defence policy as a result of the rising tension in East China Sea, namely changing in the status of Japan Self Defence Force (JSDF) as well as its defence policy.

\section{Historical Issue on the East China Sea}

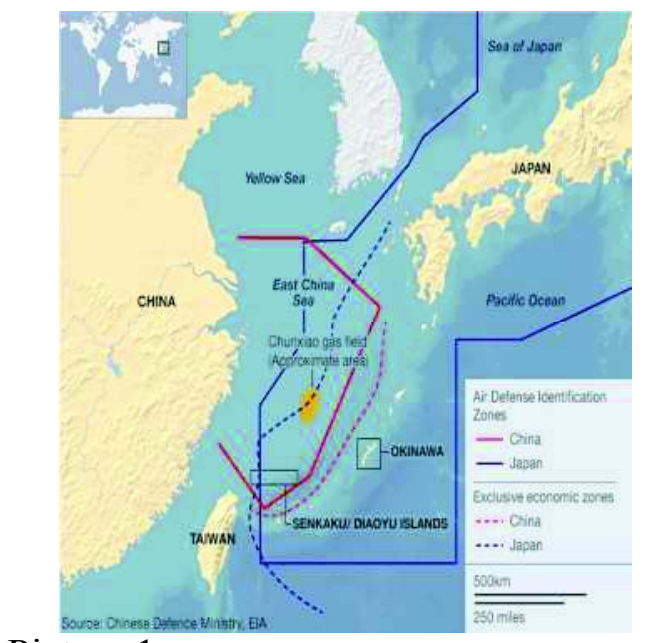

Picture 1.

Competition over a group of island based on history and sovereignty is always able to lead to military confrontation. This situation definitely happens in JapanChina relations in the East China Sea.Since 1968, Japan and China have 


\section{Shinta Puspitasari | East China Sea Dispute: Paving Japan's Way to be a Stronger Nations}

disputed East China $\mathrm{Sea}^{2}$ as a result of the United Nation Economic Commission for Asia and Far East geologists' announcement that these uninhabited islands are rich in oil and natural gas ${ }^{3}$. This is where the problem began: according to the United nations, 'a nation can claim an exclusive economic zone (EEZ) that extends 200 miles offshore'. 4 On the contrary, the width of East China Sea is merely 360 nautical miles (n.m). This being said, whoever control the East China Sea is able to claim a sovereignty over that area. This is then explain picture 1 above: both countries wants to claim East China Sea, but that's area intersected with both countries EEZ.Also, due to China and Japan are the biggest energy consumers in Asia region, it is not surprising if they compete for East China Sea.

Historically, Japan first annexed the disputed area on $1895^{5}$ through the annexation of Taiwan by the Treaty of Shimonoseki. However, since Japan lost to the U.S during World War II, all Japan's

\footnotetext{
${ }^{2}$ Senkaku (Japanese); Diaoyu (Chinese).

${ }^{3}$ Valma, p. 440.

${ }^{4}$ Daniel A. Metraux, 'The Senkaku Islands Dispute between China and Japan', Southeast Review of Asian Studies (SERAS), vol. 35, 2013, p. 222.

${ }^{5}$ This was the time when the Japanese government implemented a Cabinet Decision to include the island into Japanese territory on 14 January. However, China refused it by claiming that the area was Chinese since 16th and 17th century. (Donatello Osti, 'The Historical Background to the Territorial Dispute over the Senkaku/Diaoyu Islands', Analysis, No. 183, June 2013, p. 3-4).
}

territory became the US, including the East China Sea. Thus, it was under the US control since 1952, and returned to Japan under the 1951 San Francisco Peace Treaty and 1971 Japan-the US Okinawa Reversion Treaty ${ }^{6}$; therefore, Japan claimed East China Sea as Japan's territory based on international law. On the other hand, China also claimed the area as China's territory based on history, geography and international law: the area were Chinese since Ming dynasty and named by Chinese ${ }^{7}$. Taiwan also claimed the territory, but not as strong as China and Japan; in fact, Taiwan is quite satisfied with its relations with Japan and China ${ }^{8}$.

Since the issue over East China Sea always disturbs their relationship, Japan and China, always try to solve their problems by agreements.In 13 February 2001, for example, China and Japan agreed to sign a "confidence-building" agreement, which noted that each side should make a notification minimum two months before do an expedition close-by each other coast,

\footnotetext{
${ }^{6}$ Tetsuo Kotani, 'The Senkaku Islands and the USJapan Alliance: Future Implications for the AsiaPacific', 2049 ProjectInstitute, Kotani Futuregram 13-002, p. 2.

${ }^{7}$ Valma, p. 440.

${ }^{8}$ Stephanie Kleine-Ahlbrandt, 'A Dangerous Escalation in the East China Sea; China and Japan Must Act Now to Prevent a Worsening Territorial Dispute from Ending in Armed Conflict', Wall Street Journal (Online), 4 January 2013, http://search.proquest.com/docview/1266438111?a ccountid=10910, consulted 9 May 2013.
} 


\section{Shinta Puspitasari | East China Sea Dispute: Paving Japan's Way to be a Stronger Nations}

except in territorial water; this also includes the name of ships and their stay duration ${ }^{9}$.Nevertheless, China crossed the line on 2002 without notification, which made Japan furious. Then, they agreed to make a joint resources management in East China Seain 2008, but they failed to surmount domestic nationalist oppositions $^{10}$. The agreement has prolonged until September 2010 as a consequences for Japan's action that arrested China's fishing boat captain that crashed into Japanese sea patrol ${ }^{11}$. This incident was followed by demonstration in both countries.

Since the early 2000 s, tension in East China Sea has gradually increased due to several events. These events led to worsen their relationship. However, compare to events from 2000s, events from 2010 are more dangerous and involving military. Those events could be seen from table 1 below.

Table 1.

${ }^{9}$ Selig S. Harrison, 'Quite Struggle in the East China Sea', Current History, vol. 101, no. 65, September 2002, p. 274.

${ }^{10}$ Kleine-Ahlbrandt, 'A Dangerous Escalation in the East China Sea; China and Japan Must Act Now to Prevent a Worsening Territorial Dispute from Ending in Armed Conflict'.

${ }^{11}$ Anonymous, 'POLICY AND REGULATIONS; Islands Dispute Scuttles Sino-Japanese Energy Cooperation in East China Sea', 25 January 2013, http://www.search.proquest.com/docview/1285118 830? accountid=10910, consulted 5 May 2013.

\begin{tabular}{|c|c|}
\hline Date & Conflictual Situation \\
\hline April 2010 & $\begin{array}{l}\text { Japanese destroyer followed secretly } \\
\text { ten Chinese vessels, including Kilo- } \\
\text { class submarines and Sovremenny- } \\
\text { class destroyers, that conducted an } \\
\text { exercise in the International water } \\
\text { between Okinawa and Miyako } \\
\text { Island }^{12}\end{array}$ \\
\hline April 2010 & $\begin{array}{l}\text { PLAN hovered around Japanese } \\
\text { destroyer before returned to its host } \\
\text { ship }\end{array}$ \\
\hline $\begin{array}{c}\text { September } \\
2010\end{array}$ & $\begin{array}{l}\text { China's fishing boat hit two Japanese } \\
\text { Coast Guard's vessels near the } \\
\text { disputed islands in East China Sea }{ }^{13}\end{array}$ \\
\hline $\begin{array}{l}\text { March } \\
2011\end{array}$ & $\begin{array}{l}\text { Chinese State } \\
\text { Administration's helicopter } \\
\text { Japanese destroyer near the disputed } \\
\text { area }^{14}\end{array}$ \\
\hline $\begin{array}{c}\text { September } \\
2012\end{array}$ & $\begin{array}{l}\text { Yoshihiko Noda stated that } \\
\text { government has bought the three of } \\
\text { five islands in East China Sea from } \\
\text { its private owner and nationalized } \\
\text { them. }\end{array}$ \\
\hline
\end{tabular}

${ }^{12}$ Rory Medcalf and Raoul Heinrichs with Justin Jones, 'Crisis and Confidence: Major Powers and Maritime Security in Indo-Pacific Asia', Lowy Institute for International Policy, Australia: Longueville Media, June 2011, p. 15.

${ }^{13}$ Elena Atanassova-Cornelis, 'The Political and Security Dimension of Japan-China Relations: Strategic Mistrust and Fragile Stability', Pacific Focus: Inha Journal of International Studies, vol. 26, no. 2, August 2011, p. 178.

${ }^{14}$ Medcalf and Heinrichs with Justin Jones, p. 9

${ }^{15}$ Sheila A. Smith, 'A Sino-Japanese Clash in the East China Sea', Council on Foreign Relations, April 2013, http://www.cfr.org/eastasia/a-sinojapanese-clash-in-the-east-china-sea/, consulted 21 June 2013 
Shinta Puspitasari | East China Sea Dispute: Paving Japan's Way to be a Stronger Nations

\begin{tabular}{|c|c|}
\hline $\begin{array}{l}\text { December } \\
2012\end{array}$ & $\begin{array}{l}\text { Japan sent eight F-15 fighter jets to } \\
\text { pursue Chinese propeller plane that } \\
\text { flew through the disputed area }{ }^{16}\end{array}$ \\
\hline $\begin{array}{c}\text { January } \\
2013\end{array}$ & $\begin{array}{l}\text { Chinese navy vessel aimed a radar, } \\
\text { that usually uses for aiming weapon, } \\
\text { to Japanese navy vessel }^{17}\end{array}$ \\
\hline April 2013 & $\begin{array}{l}80 \text { Japanese activists landed on the } \\
\text { waters near the disputed islands by } \\
\text { ten boats }^{18}\end{array}$ \\
\hline $\begin{array}{l}\text { July- } \\
\text { September } \\
2014\end{array}$ & Jets scramble by Tokyo and Beijing $^{19}$ \\
\hline $\begin{array}{c}\text { March } \\
2015\end{array}$ & $\begin{array}{l}\text { China built platform no. } 2 \text { (no. } 1 \text { has } \\
\text { been built in 2013) in purpose of oil } \\
\text { and gas exploration in the East China } \\
\text { Sea close to the area claimed by both } \\
\text { countries. }\end{array}$ \\
\hline
\end{tabular}

\footnotetext{
${ }^{16}$ Kleine-Ahlbrandt, 'A Dangerous Escalation in the East China Sea; China and Japan Must Act Now to Prevent a Worsening Territorial Dispute from Ending in Armed Conflict'.

${ }^{17}$ Michael Martina, 'China, Japan Engage in New Incentive Over Disputed Islets', Reuters Website, 8 February 2013 , http://www.reuters.com/article/2013/02/08/uschina-japan-idUSBRE91704220130208, consulted 13 May 2013.

${ }^{18}$ Kaori Kaneko, 'Japan Shrine Visits, Isles Row Stir East Asia tensions', Reuters Website, 23 April 2013,

http://www.reuters.com/article/2013/04/23/usjapan-china-idUSBRE93M19I20130423, consulted 13 May 2013.

${ }^{19}$ Ben Blanchard, 'China calls on Japan to End Jet Scrambles', Reuters Website, 30 October 2014, http:/www.reuters.com/article/2014/10/30/uschina-japan-idUSKBN0IJ0SN20141030, consulted on 2 September 2015.

${ }^{20} \mathrm{ABC}$, 'China Says It Has Every Right to Drill in East China Sea Close to Waters Disputed with Japan', $A B C$ Website, 25 July 2015,www.abc.net.au/news/2015-07-25/twochinese-built-platforms-in-the-east-chinasea/6647650, conducted on 2 September 2015
}

\begin{tabular}{|c|l|}
\hline \multirow{2}{*}{$\begin{array}{c}\text { China conducted trainings on air and } \\
2015\end{array}$} & $\begin{array}{l}\text { sea in a large-scale, which involved } \\
100 \text { ships, numbers of aircraft, and } \\
100 \text { missiles. }^{21}\end{array}$ \\
\hline
\end{tabular}

As we could see from the table, most of the incidents in the East China Sea has now involved military. Evaluating these facts, Japan's policy makers start to think whether they have protected their border properly. As a result, Japan starts to act.

\section{Japan's Defence Policy Prior Changing}

Since the new Showa Constitution established, article $9^{22}$ has been the basic foundation of Japan's defence policy.Start with article 9 as a foundation, Japanese governments then tried to interpret it as far as they can, and established a Basic Policy

\footnotetext{
${ }^{21}$ Megha Rajagopalan, 'China Conducts Air, Sea Drills in East China Sea', Reuters Website, 27 August 2015 , http://www.reuters.com/article/2015/08/27/uschina-defence-idUSKCN0QW1EX20150827, consulted on 2 September 2015.
}

${ }^{22}$ Article 9 Showa Constitution (1946): "Renunciation War" stated, "Aspiring sincerely to an international peace based on justice and order, the Japanese poeple forever renounce war as a sovereign right of the nation and the threat or use force as means of settling international disputes. In order to accomplish the aim of preceding paragraph, land, sea, and air forces, as well as other war potential, will never be maintained. The right of belligerency of the state will not be recognized." (Kishimoto Koichi, Politics in Modern Japan: Development and Organization (3rd edition), Tokyo, July 1988, p. 156). 


\section{Shinta Puspitasari | East China Sea Dispute: Paving Japan's Way to be a Stronger Nations}

for National Defence in May $1957^{23}$.This policy, contained four principle that aimed to achieve purpose in Japan's defence, based on two tenets: article 9 Japan's Constitution and reliance on the US in a more big scale threat to Japan's security (for example, nuclear threat).These principles are: first, supporting the United Nations' (UN) activity and working together with other nations in order to promote world peace. Second, promote public welfare and increase nationality by establishing the foundation for Japan's security. Third, advance progressively the effective defence capabilities only for selfdefence according to national capacities and circumstances. Four, deal with foreign invasion based on Japan-US security formulation until the $\mathrm{UN}$ is able to prevent such threats. ${ }^{24}$

Moreover, besides those four principles, on 1976, Miki Government passed a Basic Outline of National Defence and added six other points, which known as Non-Constitutional Principles. Those points are adhering the Three NonNuclear Principles, not possessing military power apart from self-defence limitation, possesing exclusive defence-oriented

\footnotetext{
${ }^{23}$ Senate Standing Committee on Foreign Affairs, Defence and Trade, Japan's Defence and Security in the 1990's, Australia, June 1993, p. 50.

${ }^{24}$ Ministry of Defence, 'Japan's Annual White Paper 2011', Japan's Ministry of Defence Website, 2011, www.mod.go.jp/e/publ/w_paper/pdf/2011/, consulted 5 June 2013, p. 139.
}

policy, asserting Diet control over the military, adhering Three Principles on Arms Exports (1967), and keeping military budget strictly to one per cent of Gross National Product (GNP). ${ }^{25}$ With the two tenets as the ground and principles following it, Japan's government hasestablished various National Defence Programs since 1958, also known as MidTerm Develoment Program (MTDP) since 1976, and included the details of Japan Self Defence Forces' development, staff, equipment, and funding for five years term. $^{26}$

Falling of Soviet Union as a result of defeat from the US in the Cold War also brought advantage for Japan:Japan obtained several defence policy as well as foreign policy options. These policy options, according to J.A.A Stockwin in his book Governing Japan: Divided Politics in a Resurgent Economy, consists of three options. The first option is transforming into 'pacifist' country, which is in line with article 9 Constitution. The second option is continuation of status quo under the Mutual Security Treaty with the US. The third option, and the radical option, is cutting any correlation with the US on security and boosting Japan's own

\footnotetext{
${ }^{25}$ Senate Standing Committee on Foreign Affairs, Defence and Trade, p. 51-52.

${ }^{26}$ Senate Standing Committee on Foreign Affairs, Defence and Trade, p. 53.
} 


\section{Shinta Puspitasari | East China Sea Dispute: Paving Japan's Way to be a Stronger Nations}

defence capability; therefore, Japan will be able to bring its own interest to the front instead of the US. ${ }^{27}$ The fourth option is promoting Japan-China security alliance; however, only a few people who would consider this option: Japan and China might be a good partner for economy, but they have a very cold political and security relations. The last option for Japan's security policy will be increasing ties between Japan-the US, which became popular in Koizumi's term. ${ }^{28}$

Indeed, the last option is the favourable option for Japan's government. Japan still needs the US protection; therefore, Japan needs to strengthen its relations with the US. This choice was seen in the 1995 National Defence Policy Guidelines (NDPG) for Fiscal Year (FY) 1996. 1995 NDPG, which formulated as a result ofan increasing expectation on SelfDefence Force (SDF) to react in the changes in international situation, still held the Basic Defence Force Concept; in fact, it was only reviewing the scale and functions of defence ability with focusing on using the SDF for not only Japan's defence but also other fields. ${ }^{29}$ In the review, Japanese government agreed to

${ }^{27}$ J. A. A. Stockwin, Governing Japan: Divided Politics in a Resurgent Economy (fourth edition), UK: Blackwell Publishing, 2008, p. 248.

${ }^{28}$ Stockwin, p. 249.

${ }^{29}$ Ministry of Defence, 'Japan's Annual White Paper 2011', p. 143. keep rely on the US on security; fundamentally, there was no change from 1976 NDPG.

The next NDPG was set on 2004 for FY 2005. The new NDPG started to recognize threats from international setting such as terrorisms, and rapid growth of weapon of mass destruction and ballistic missile. ${ }^{30}$ In addition, there was an issue of additionalchapter on the outline, and it indeed added some new components for NDPG. For the first time, NDPG explains the basic principles of Japan's defence policy: two goals, three approaches. The two goals were preventing any threats from surrounding Japan while minimazing any negative effects, and improving international environment to get the first goal; the three approaches that Japan will use were from within Japan, and cooperation with both regional and international community. ${ }^{31}$

\section{Furthermore, $2004 \quad$ NDPG} presented a new concept for defence force. Since Japan acknowledged the potential threats to the country, it proposed that it is difficult to improve defence capability only based on Basic Defence Force Concept; therefore, according to the 2004 NDPG, it is important for SDF to

\footnotetext{
${ }^{30}$ Ministry of Defence, 'Japan's Annual White Paper 2011', p. 144.

${ }^{31}$ Ministry of Defence, 'Japan's Annual White Paper 2011', p. 144.
} 


\section{Shinta Puspitasari | East China Sea Dispute: Paving Japan's Way to be a Stronger Nations}

cooperate with international community in order to defend Japan and increased relations with the US; coordination with non-governmental organization also noted for the first time.$^{32}$ Moreover, the new NDPG also noted that Japan's defence forces need "multifunctional, flexible, and effective defence capability", which bolstered by "high technological and intelligence capabilities; this require Japan to not only react to ballistic missile threats but also other security threats. However, the plan did not work due to the lack of resources and funding. At the end of discussion between Ministry of Finance (MOF) and Japan Defence Agency (JDA), MOF clearly won. Yet, National Defence Programs Outline (NDPO) 2004 set a new goal in Japanese defence policy. ${ }^{33}$ Besides, with the new developments in the East China Sea, Japan cannot still use the same defence policy: it definitely has to change its defence policy.

\section{Changing in Japan's Defence Policy}

Japan-China dispute over East China Sea is not a new trend. However, the situation is different: today, it is more dangerous than in the past. The attempts to

\footnotetext{
${ }^{32}$ Yuki Tatsumi, 'National Defence Program Outline: A New Security Policy Guideline or a Mere Wish List?', Japan Watch, 20 December 2004.

${ }^{33}$ Yuki Tatsumi, 'National Defence Program Outline: A New Security Policy Guideline or a Mere Wish List?'.
}

claim this uninhabited island has finally involved military operations from Japan and China. As we could see from Table 1 above, this situation is repeated every year with increasing tension in each year. With this development, it is not a surprise when Japanese policy makers think what should they do to secure their border. ${ }^{34}$ This then come to an idea to make changes in Japan's defence policy. There are two main points that are changing in Japan's defence policy: reinterpretation of Article 9 Japanese Constitution andself-defence force status.

Since the establishment of Self Defence Force (SDF) in 1954, ${ }^{35}$ Japanese government strictly points its defence policy at National Defence Program Guidelines 1976, which updated in 1995 and 2004.However, basic self-defence forces concept that Japan adheres is changing now due to security environment surrounding Japan, namely rising China's economy, tension in East China Sea, increasing China's military budget, and North Korea nuclear threat.If in 2004 Japan was only show its concern about the possibility of China's military expansion, now Japan really considers to react.In fact, since 2008, Japanese government were

\footnotetext{
${ }^{34}$ Fouse, p. 7.

${ }^{35}$ Koichi, p. 46. (Before turn into SDF, Japan has a National Police Reserved that established in 1950, then renamed into Safety Forces in 1952).
} 


\section{Shinta Puspitasari | East China Sea Dispute: Paving Japan's Way to be a Stronger Nations}

concerned about China's growing military activity and increasing military budget, especially about what happened in East China Sea.Thus, in December 2010, under Prime Minister Naoto Kan from Democratic Party of Japan (DPJ), Japan released its Japan Basic Defence Program for FY 2011 to 2015. This new defence policy approves SDF to move quickly and effectively to handle threats surrounding Japan. $^{36}$

Before the new NDPG was published on December 2010, however, there are several proposals to the government that might be the base of the next NDPG, even though not all of these proposals approved. One of them is defence shift from static (Basic Self Defence Force) to dynamic (Dynamic Self Defence Force). This is quite controversial because Japan will no longer use the same concept that governs Japan's defence policy since 1976. Another proposal that is quite controversial is reviewing Three Non-Nuclear Principles. ${ }^{37}$

\footnotetext{
${ }^{36}$ Sheila A. Smith, 'Japan's 'Dynamic Defence' Policy and China', Council on Foreign Relations Website, 17 December 2010, http://www.cfr.org/japan/japans-dynamic-defensepolicy-china/p23663, consulted 21 June 2013.

37 Axel Berkofsky, 'Japanese Defence Policy Stepping It Up Or Status Quo?', International Relations and Security Network (ISN) Website, 22 November 2010,http://www.isn.ethz.ch/DigitalLibrary/Articles/Detail/?ots591=4888caa0-b3db-
}

Regarding shifting of SDF status from static to dynamic, government published the approved changing on 17 December 2010.Dynamic Defence Force will allow Japan to focus its defence attempts to what nation needs, not merely sustaining the minimum defence capacity to avoid a power vacuum in the region. ${ }^{38}$ In addition, since the new NDPG constructed as a response to increasingly threats from international environment, Japan also develop a "dynamic deterrence". This means that Japan should be able to dealing with any threats, and this purpose will be achieved if Japan could monitor its air and sea area. ${ }^{39}$ This changing is considered controversial because it happened under DPJ central-left leadership.

However, situation in East China Sea and increasingly "gray zone" (dispute over territory, sovereignty, and economic interest) disputes change the core concept in 2010 defence policy to be how to cope with the "gray zone" with emphasize on spreading Japan's intelligence, surveillance and reconnaissance (ISR) capabilities in the southern islands.In addition, it designed to construct a more active, organized and flexible defence

1461-98b9-e20e7b9c13d4\&lng=en\&id=124213, consulted 21 June 2013.

${ }^{38}$ Fouse, p. 4.

${ }^{39}$ Ministry of Defence, 'Japan's Annual White Paper 2011', p. 149. 


\section{Shinta Puspitasari | East China Sea Dispute: Paving Japan's Way to be a Stronger Nations}

force that be able to respond immediately to any threat that might happen there.In order to achieve that, Japanese government will spread the SDF personnel from Hokkaido far-reaching to the southern area, almost to Taiwan and Chinese mainland; Ground Self Defence Forse (GSDF) will also obtain more $\mathrm{CH}-47$ JA Transport helicopters and Air Self Defence Force (ASDF) will familiarize a substitute for the previous $\mathrm{C}-1$ transport aircraft. ${ }^{40}$

In addition to that, Japan's government will also adds some new equipments such as helicopter destroyers (DDH), destroyers (DD), submarines, and fixed-wing surveillance aircraft (P-1) while prolong the previous submarines, destroyers and P3-C fixed-wing surveillance aircraft. $^{41}$ Moreover, Japan also will provided additional support for warning aircraft (E-2C) along with active early warning radar in the South-western islands. Furthermore, defence ministry also wants to distribute 100 non-combat Ground Self Defence Force (GSDF) to Yonaguni Island, Miyako and Ishigaki Island. Also, there will be a power enhancement for GDSF 15th Brigade in Naha. $^{42}$

\footnotetext{
${ }^{40}$ Fouse, p. 4.

${ }^{41}$ Fouse, p. 7.

${ }^{42}$ Fouse, p. 7.
}

This changes will be accompanied by a new policy called Collective Self-Defence. This will happen if Japan succeed to reinterpret Article 9 Showa Constitution. Collective Self-Defence is a policy that make Japanese Self-Defence Force able to go overseas in order to resolve conflicts. This law will be active when there is a danger to Japan or Japan's ally that could affect Japan and its people. ${ }^{43}$ Also, the government will use this law if there is no other way to avoid attact towards Japan. This action will also include enlarging a defence border of Maritime Self-Defence Force, permitting the Self-Defence Force to help the United nations peacekeeping operations overseas, help US military performance in Afghanistan and Iraq, elevating Japan Defence Agency status to be full ministry, and increasing trilateral military cooperation between the US, Australia, and Japan. ${ }^{44}$ Though it means that by applying this law Japan is abandoning its Article 9 Showa Constitution, this action is needed to ensure Japan's security. As Abe, Japan's Prime Minister, said on a press conference,

"We live in an era when no country can any longer protect itself alone. In the

\footnotetext{
${ }^{43}$ BBC, 'Japan's Lower House Approves Change to Self-Defence law', BBC Website, 16 July 2015, http://bbc.com, consulted on 2 September 2015

${ }^{44}$ T.J. Pempel, 'Why Japan's Collective SelfDefence is so Politicised', East Asia Forum, 1 September 2014, p. 1.
} 


\section{Shinta Puspitasari | East China Sea Dispute: Paving Japan's Way to be a Stronger Nations}

past two years, Japanese nationals have fallen victim to terrorism in Algeria, Syria and Tunisia; Japan is within range of hundreds of North Korea's ballistic missiles and the number of (fighter jet) scrambles has risen seven-fold in a decade.This is the reality. We should not try to ignore it ${ }^{\text {, } 45}$

In the middle of February, in addition, the LDP started to discuss this issue with its coalition, Komeito. ${ }^{46}$ Also, the Prime Minister wanted to propose a troops' deployment overseas without permission from Diet before hand. ${ }^{47}$ Then, on 15 July 2015, a special committee set up in Japan's lower house to discuss on new security bills proposed by LDP. ${ }^{48}$ After that, they will proposed this to the lower house. Indeed, LDP has to win a majority vote from upper house, but since LDP has the majority members on Diet, many experts expect them to win the debate so the bill will be issued. ${ }^{49}$ However, these changes do not mean that Japan will no longer develop a strong

\footnotetext{
${ }^{45}$ BBC, 'Japan Self-Defence Laws Reform Backed by Cabinet', $B B C$ Website, 14 May 2015, http://www.bbc.com/news/world-asia-32735359, consulted on 2 September 2015.

${ }^{46}$ J. Patrick Boyd, 'The Perils of legislating Abe's Collective Self-Defence', East Asia Forum, 19 March 2015, p. 1.

${ }^{47}$ Boyd, p. 1.

${ }^{48} \mathrm{BBC}$, 'Protest as Japan Paves Way for SelfDefence Law Change', BBC Website, 15 July 2015, http://www.bbc.com/news/world-asia-33532557, consulted on2 September 2015.

${ }^{49} \mathrm{BBC}$, 'Japan's Lower House Approves Change to Self-Defence law'.
}

relationship with the US. On the contrary, Japan-US relations will be stronger now than before. This is shown by the US President Barrack Obama's statement when he visited Japan in 2014:

“Our commitment to Japan's security is absolute and article five [of the security treaty] covers all territories under Japan's administration, including the Senkaku islands.We don't take a position on final sovereignty on the Senkakus but historically they've been administered by Japan and should not be subject to change unilaterally. ",50

This vision is then reaffirmed by the US Secretary of State, John Kerry, on his press conference in Washington with Japan's foreign and defence minister. ${ }^{51}$

Another controversial proposal is reviewing the Three Non-Nuclear Principles. ${ }^{52}$. This vision was similar to

\footnotetext{
${ }^{50}$ Justin McCurry and Tania Branigan, 'Obama Says US will Defend Japan in Island Dispute with China', The Guardian Website, 24 April 2014, http://www.theguardian.com/world/2014/apr/24/ob ama-in-japan-backs-status-quo-in-island-disputewith-china, consulted on 2 September 2015.

${ }^{51}$ Matt Spetalnick, 'Kerry Renews US Pledge to Japan Security, including East China Sea Islets', Reuters Website, 28 April 2015, http://www.reuters.com/article/2015/04/28/us-usajapan-defense-kerry-idUSKBN0NI1SI20150428, consulted on 2 September 2015.

52 Axel Berkofsky, 'Japanese Defence Policy Stepping It Up Or Status Quo?', International Relations and Security Network (ISN) Website, 22 November 2010,http://www.isn.ethz.ch/DigitalLibrary/Articles/Detail/?ots591=4888caa0-b3db-
} 


\section{Shinta Puspitasari | East China Sea Dispute: Paving Japan's Way to be a Stronger Nations}

Robert Dujarric, Director of the Institute of Contemporary Asian Studies (ICAS) at Temple University in Tokyo. According to Dujarric, at least one of the three principals will be detached in December. Dujarric bases his view with the fact that the US has introduced Japan with the nuclear since the principle was announced. For all these time, Japan never ban the US nuclear in Japan, and will not intend to do so in the future either. However, according to Japanese Foreign ministry, Japan will not change the Three Non-Nuclear Principles in December. As he said, "Reviewing any non-nuclear principles will remain a taboo in December and long after that." ${ }^{, 53}$ This statement was also supported by Koizumi Junichiro (Japan's former Prime Minister), who recommended 'zero nuclear' to Japan's current Prime Minister, Abe Shinzō. ${ }^{54}$

In addition, the new NDPG signify that Japan will form a new body within the Prime Minister's office to poise the security issues with other pertinent ministers and provide recommendations to

1461-98b9-e20e7b9c13d4\&lng=en\&id=124213, consulted 21 June 2013.

53 Kiyoshi Takenaka and Robert Birsel, 'Japan's ex-PM Koizumi Urges Abe to Abandon Nuclear Power', Reuters Website, 12 November 2013, http://www.reuters.com/article/2013/11/12/usjapan-nuclear-koizumi-

idUSBRE9AB0HK20131112, consulted 3 December 2013.

54 Takenaka and Birsel, 'Japan's ex-PM Koizumi Urges Abe to Abandon Nuclear Power'.
Prime Minister after assessing the structure and function of existing security organizations in cabinet. ${ }^{55}$ With the new defence policy, it is not a surprise when China against it.

However, there are some concerns about these changes, and one of them is related to Japanese financial situation.Changing in Japan's security policy means that Japan needs to provide equipments to support the changes. Nevertheless, Japan has a fiscal deficit and continuously increasing social security costs that makes spending more money for defence seems implausible. As Azumi, the vice-minister stated, "before you can fight China, you have to go to war with the finance ministry". 56 Moreover, government has decided to cut the budget up to five per cent for over three or four years; this makes experts doubt about the continuation of the new proposal. ${ }^{57}$ It does not seem possible for Japan to upgrade its

55 Axel Berkofsky, 'Japan's Defense and Security Policies: What's Old, What's New, What's Ahead', Konrad-Adenauer-Shiftung (KAS) Website, February 2012, www.kas.de/japan, consulted 5 May 2013.

${ }^{56}$ Mure Dickie, 'Japan to Shift Military Towards China Thread', Financial Times Website, 13 December 2010, http://www.ft.com/cms/s/0/cac4bfec-05d7-11e0976b-00144feabdc0.html\#axzz2WphDA98w, consulted 21 June 2013.

${ }^{57}$ Axel Berkofsky, 'Dissecting Japan's New Defence Guidelines', Geopolitical Monitor Intelligence Website, 16 February 2011, http://www.geopoliticalmonitor.com/dissectingjapans-new-defense-guidelines-4294/, consulted 21 June 2013. 


\section{Shinta Puspitasari | East China Sea Dispute: Paving Japan's Way to be a Stronger Nations}

equipment with limited budget, but MoD still hopes that Japan will do more within the budget limitation. Nevertheless, Abe's administration indeed intends to increase defence budget, but it raises another question, which is whether Japan can afford it for the long term. ${ }^{58}$

This concern, however, seems untrue since Japanese government has started to formulate a new National Defence Program Guidelines (NDPG). In fact, Japanese government has planned to reform the NDPG at the end of 2013. As the tension between Japan-China-North Korea-South Korea increase recently, Japanese government stated that Japan will amend its defence policy and weapons purchase plan by December $2013^{59}$. Abe, Japanese Prime Minister, also stated that he wants to loosen the limitation in the article 9 Showa Constitution 1946. According to Yomiuri newspaper, Japanese governments will postpone the current NDPG that forms Japan's defence policy for the next ten years and defence shopping list for the next five years while

\footnotetext{
${ }^{58}$ Nakanishi Hiroshi, 'Priorities for Japan's Defence Policy', Nippon Communication Foundations, 12 March 2013 , http://www.nippon.com/en/currents/d00071/, consulted 21 June 2013.

${ }^{59}$ Kiyoshi Takenaka and Michael Perry, 'Japan to Revise Defence Policy by the End 2013: Paper', Reuters Website, 7 January 2013, http://www.reuters.com/article/2013/01/08/usjapan-defence-idUSBRE90701K20130108, consulted 21 June 2013.
}

they arrange for the new ones by December. In addition, according to Yomiuri, the governments want to increase the defence budget up to more than a hundred billion yen a year (start in April) in order to defray the fuel, repairing patrol planes, and research on radar technology; this will be the first increasing budget for eleven years. ${ }^{60}$

Another concern is related to power shift in Japanese political system. The 2009 defence policy proposal was made by Liberal Democratic Party (LDP) as the ruling party at that time. Therefore, when the LDP lost at the 2009 election, experts doubted that the proposal will be accepted since the winner party was DPJ, and DPJ seemed more hesitant about missile and more emphasizing on 'soft power' towards China rather than LDP. As a proved, DPJ Foreign Minister, Okada, insisted that government suppose to be able to explain to public the cost that Japan spent for developing missile defence system with the US. This was also followed by fund suspension for PAC-3 distribution at least until April 2011 by DPJ cabinet. ${ }^{61}$ Besides, in the security proposal for Hatoyama administration, the

\footnotetext{
${ }^{60}$ Kiyoshi Takenaka and Michael Perry, 'Japan to Revise Defense Policy by the End 2013: Paper'.

${ }^{61}$ Masako Toki, 'Japan's Defence Guidelines: New Conventional Strategy, Same Old Nuclear Dilemma', NTI Website, 1 March 2011, http://www.nti.org/analysis/articles/japans-defenseguidelines/, consulted 5 June 2013.
} 


\section{Shinta Puspitasari | East China Sea Dispute: Paving Japan's Way to be a Stronger Nations}

governments clearly stated that they will not use any forces; instead, the proposal emphasizes the importance of Japan-the US alliance, ties with Asia, and Japan's role in international community for peacekeeping. ${ }^{62}$ Nevertheless, the LDP has won the election in 2012 as well as 2014, which changes the majority in parliament and put Abe as Japan's Prime Minister. As a consequence, Abe's chance to release a new defence policy is quite big.

The proposal that constructed by the ruling party LDP has been released last month amongst specific groups. According to the proposal, Japan should develop its military capability while support its navy and $\operatorname{army}^{63}$. In this new proposal, Japan does not mention its concern about China and North Korea, but it includes some controversial issues. The most controversial is the offered discussion about pre-emptive strike capabilities that require Japan to upgrade or build some equipments. In addition, Japan is also gradually building its Ballistic-Missile Defence system (BMD), which enable

\footnotetext{
${ }^{62}$ The Tokyo Foundation, 'Japan's Security: 10 Proposal for the Hatoyama Administration', The Tokyo Foundation Website, October 2009, http://www.tokyofoundation.org/en/, consulted 9 May 2013.

${ }^{63}$ Paul Kallender-Umezu, 'Japan Plans More Aggressive Defense', Defense News Website, 26 May 2013 , http://www.defensenews.com/article/20130526/DE FREG03/305260004/Japan-Plans-More-

Aggressive-Defense, consulted 21 June 2013.
}

Japan to launch missile to North Korea under certain circumstances ${ }^{64}$. According to some analysts, Japan probably will not develop separate marine soldier, but it more likely fortifies its amphibious capability $^{65}$.

In general, Japan's action against China will likely to get support in region, given China's aggressive military expansion. However, this proposal calls for more considerations. According to Paul Giarra, president of US-based consulting Global Strategies and Transformation company, Japan needs to consider its neighbors' perspective; this new proposal seems very radical so that raising concern in Asia and the US. ${ }^{66}$ As Giarra states,

The question is whether Japanese officials can resist the temptation to undo what they believe were unnecessary apologies for wartime actions they don't believe were wrong. The feeling of being wronged is as powerful in Japan as it is the other way around in Korea, Philippines, Indonesia . . . Germany dealt with its past and continues to do so, but Japan suppressed the issue, creating pent

\footnotetext{
${ }^{64}$ Paul Kallender-Umezu, 'Japan Plans More Aggressive Defense'.

${ }^{65}$ Paul Kallender-Umezu, 'Japan Plans More Aggressive Defense'.

${ }^{66}$ Paul Kallender-Umezu, 'Japan Plans More Aggressive Defense'.
} 


\section{Shinta Puspitasari | East China Sea Dispute: Paving Japan's Way to be a Stronger Nations}

up pressure, and when it vents, it could change how this buildup is seen.

Thus, this proposal still needs more discussions between LDP members and Ministry of Defence. Although lower an upper house in the Diet may support these changes, it may not so easy to confince Japanese to support this because they still prefer Japan to be a pacifist country. Besides, Ministry of Finance may not want to increase budget for defence expenditure. $^{67}$

\section{Conclusion}

Dispute over East China Sea between Japan and China has occured since 1968 due to UN's inspection result that the East China Sea is rich with natural resources. That is why this matter always becomes a major problem between two countries. Moreover, sequence of events that has risen since 2008, and become worse by the time, make Japan government decided to renew their defence forces. They cannot reform their defence forces into offensive forces due to constitution restriction, but they can change it into something new, namely Dynamic Defence Forces. Some experts believe that this cannot be happen due to financial problem, and power shift in

${ }^{67}$ Paul Kallender-Umezu, 'Japan Plans More Aggressive Defense'.
Japan's government, but rising tension in East China Sea and environment surrounding Japan change everything: Japan needs a new defence forces. Therefore, in 2010, Japan government passed a new defence policy and its defence forces for FY2011 and beyond. Moreover, due to increasing conflict with China on the East China Sea issue, Japanese government try to reinterpret Article 9 Constitution so it can be in accordance with their new proposal. This plan is called Collective Self-Defence. This new change may look abandoning to Japan's Article 9 Constitution, but this changes is needed, especially after the new developments surrounding Japan.

\section{Bibliography:}

\section{Books:}

Koichi, Kishimoto, Politics in Modern Japan: Development and Organization (3rd edition), Tokyo, July 1988.

Senate Standing Committee on Foreign Affairs, Defence and Trade, Japan's Defence and Security in the 1990's, Australia, June 1993.

Stockwin, J. A. A., Governing Japan: Divided Politics in a Resurgent Economy (fourth edition), UK: Blackwell Publishing, 2008. 
Shinta Puspitasari | East China Sea Dispute: Paving Japan's Way to be a Stronger Nations

Article:

Anonymous, 'Why These Anti-Japanese Protests are Different', The Lowy Institute, September 2012, http://www.thelowyinstitute.org, consulted 5 May 2013.

Berkofsky, Axel, 'Dissecting Japan's New Defence Guidelines', Geopolitical Monitor Intelligence Website, 16 February 2011, http://www.geopoliticalmonitor. com/dissecting-japans-newdefense-guidelines-4294/, consulted 21 June 2013.

Berkofsky, Axel, 'Japanese Defence Policy - Stepping It Up Or Status Quo?', International Relations and Security Network (ISN) Website, 22 November 2010 , http://www.isn.ethz.ch/DigitalLibrary/Articles/Detail/?ots591= 4888caa0-b3db-1461-98b9e20e7b9c13d4\&lng=en\&id $=124$

213, consulted 21 June 2013.

Berkofsky, Axel, 'Japan's Defence and Security Policies: What's Old, What's New, What's Ahead', Konrad-Adenauer-Shiftung

(KAS) Website, February 2012, www.kas.de/japan, consulted 5 May 2013.

Boyd, J. Patrick, 'The Perils of legislating Abe's Collective Self-Defence', East Asia Forum, 19 March 2015.

Dickie, Mure, 'Japan to Shift Military Towards China Thread', Financial Times Website, 13 December 2010, http://www.ft.com/cms/s/0/cac4 bfec-05d7-11e0-976b00144feabdc0.html\#axzz2Wph DA98w, consulted 21 June 2013.

Hiroshi, Nakanishi, 'Priorities for Japan's Defence Policy', Nippon Communication Foundations, 12 March 2013, http://www.nippon.com/en/curre nts/d00071/, consulted 21 June 2013.

Kent E., Calder, 'China and Japan's Shimmering Rivalry', Foreign Affairs, vol. 85 no. 2, 2006, p. 129.

Kotani, Tetsuo,'The Senkaku Islands and the US-Japan Alliance: Future Implications for the AsiaPacific', 2049 Project Institute, Kotani Futuregram 13-002.

Pempel, T.J., 'Why Japan's Collective Self-Defence is so Politicised', 
Shinta Puspitasari | East China Sea Dispute: Paving Japan's Way to be a Stronger Nations

East Asia Forum, 1 September 2014.

Smith, Sheila A., 'Japan's 'Dynamic

Defence' Policy and China', 17

December 2010, Council on

Foreign Relations Website, http://www.cfr.org/japan/japans-

dynamic-defense-policy-

china/p23663, consulted 21 June 2013.

Takenaka, Kiyoshi and Perry, Michael, 'Japan to Revise Defence Policy by the End 2013: Paper', Reuters Website, 7 January 2013,

http://www.reuters.com/article/2

013/01/08/us-japan-defence-

idUSBRE90701K20130108,

consulted 21 May 2013.

Tatsumi, Yuki, 'National Defence Program

Outline: A New Security Policy

Guideline or a Mere Wish

List?', Japan Watch, 20

December 2004.

Toki, Masako, 'Japan's Defence

Guidelines: New Conventional

Strategy, Same Old Nuclear

Dilemma', NTI Website, 1

March

2011,

http://www.nti.org/analysis/artic

les/japans-defense-guidelines/,

consulted 5 June 2013.

Journals:
Anonymous, 'Dispute Deepens Between China, Japan Over East China Sea', Energy Intelligence Group, 21 September 2005, http://search.proquest.com/docvi ew/199232460? accountid=1091 0, consulted 11 April 2013.

Atanassova-Cornelis, Elena, 'The Political and Security Dimension of Japan-China Relations: Strategic Mistrust and Fragile Stability', Pacific Focus: Inha Journal of International Studies, vol. 26, no. 2, August 2011, pp. 165187.

Fouse, David, ‘Japan's 2010 National Defence Program Guidelines: Coping with the "Grey Zones", Asia-Pacific Centre for Security Studies, April 2011.

Harrison, Selig S., 'Quite Struggle in the East China Sea', Current History, vol. 101, no. 65, September 2002, pp. 271-277.

Medcalf, Rory and Heinrichs, Raoul with Jones, Justin, 'Crisis and Confidence: Major Powers and Maritime Security in IndoPacific Asia', Lowy Institute for International Policy, Australia: Longueville Media, June 2011. 
Shinta Puspitasari | East China Sea Dispute: Paving Japan's Way to be a Stronger Nations

Metraux, Daniel A., 'The Senkaku Islands

Dispute between China and Japan', Southeast Review of Asian Studies (SERAS), vol. 35, 2013.

Osti, Donatello, 'The Historical Background to the Territorial Dispute over the Senkaku/Diaoyu Islands', Analysis, No. 183, June 2013, pp. 1-9.

The Tokyo Foundation, 'Policy Proposal Japan Strategy Towards China: Integration, Balancing and Deterrence in the Era of Power Shift', The Tokyo Foundation, October 2011.

Varma, Lalima, 'Japan-China Relations: Problems and Prospects in the 21st Century', China Report, vol. 29, no. 4, 1993, pp. 437454.

News:

ABC, 'China Says It Has Every Right to Drill in East China Sea Close to Waters Disputed with Japan', ABC Website, 25 July 2015, www.abc.net.au/news/2015-0725/two-chinese-built-platformsin-the-east-china-sea/6647650, conducted on 2 September 2015.
BBC, 'Japan's Lower House Approves Change to Self-Defence law', $B B C$ Website, 16 July 2015, http://bbc.com, consulted on 2 September 2015.

BBC, 'Japan Self-Defence Laws Reform Backed by Cabinet', $B B C$ Website, 14 May 2015, http://www.bbc.com/news/world -asia-32735359, consulted on 2 September 2015.

BBC, 'Protest as Japan Paves Way for Self-Defence Law Change', $B B C$ Website, 15 July 2015, http://www.bbc.com/news/world -asia-33532557, consulted on2 September 2015.

Blanchard, Ben, 'China calls on Japan to End Jet Scrambles', Reuters Website, 30 October 2014, http://www.reuters.com/article/2 014/10/30/us-china-japanidUSKBNOIJ0SN20141030, consulted on 2 September 2015.

Kallender-Umezu, Paul, 'Japan Plans More Aggressive Defense', Defense News Website, 26 May 2013, http://www.defensenews.com/ar ticle/20130526/DEFREG03/305 260004/Japan-Plans-More- 
Shinta Puspitasari | East China Sea Dispute: Paving Japan's Way to be a Stronger Nations

Aggressive-Defense, consulted

21 June 2013.

Kaneko, Kaori, 'Japan Shrine Visits, Isles

Row Stir East Asia tensions',

Reuters Website, 23 April 2013, http://www.reuters.com/article/2

013/04/23/us-japan-china-

idUSBRE93M19I20130423,

consulted 13 May 2013.

Kleine-Ahlbrandt, Stephanie, 'A

Dangerous Escalation in the East China Sea; China and Japan

Must Act Now to Prevent a

Worsening Territorial Dispute from Ending in Armed Conflict', Wall Street Journal (Online), 4 January 2013, http://search.proquest.com/docvi ew/1266438111 accountid=109 10, consulted 9 May 2013.

Martina, Michael, 'China, Japan Engage in New Incentive Over Disputed Isles', Reuters Website, 8 February 2013 , http://www.reuters.com/article/2 013/02/08/us-china-japanidUSBRE91704220130208, consulted 13 May 2013.

Martina, Michael, Standing, Jonathan, and Popeski, Ron, 'Japan Envoy Says Territory Disputes with China Can Be Resolved',
Reuters Website, 25 January 2013,

http://www.reuters.com/article/2

013/01/25/us-china-japan, consulted 13 May 2013.

McCurry, Justin and Branigan, Tania, 'Obama Says US will Defend Japan in Island Dispute with China', The Guardian Website, 24 April 2014, http://www.theguardian.com/wo rld/2014/apr/24/obama-in-japanbacks-status-quo-in-islanddispute-with-china, consulted on 2 September 2015.

Rajagopalan, Megha, 'China Conducts Air, Sea Drills in East China Sea', Reuters Website, 27 August 2015 , http://www.reuters.com/article/2 015/08/27/us-china-defenceidUSKCN0QW1EX20150827, consulted on 2 September 2015.

Smith, Sheila A., 'A Sino-Japanese Clash in the East China Sea', Council on Foreign Relations, April 2013, http://www.cfr.org/eastasia/asino-japanese-clash-in-the-eastchina-sea/, consulted 21 June 2013.

Matt Spetalnick, 'Kerry Renews US Pledge to Japan Security, 
Shinta Puspitasari | East China Sea Dispute: Paving Japan's Way to be a Stronger Nations

including East China Sea Islets',

Reuters Website, 28 April 2015,

http://www.reuters.com/article/2

015/04/28/us-usa-japan-defense-

kerry-

idUSKBN0NI1SI20150428,

consulted on 2 September 2015.

Takenaka, Kiyoshi and Birsel, Robert,

'Japan's ex-PM Koizumi Urges

Abe to Abandon Nuclear

Power', Reuters Website, 12

November 2013,

http://www.reuters.com/article/2

013/11/12/us-japan-nuclear-

koizumi-

idUSBRE9AB0HK20131112,

consulted 3 December 2013 /pdf/2011/, consulted 5 June 2013.

The Tokyo Foundation, 'Japan's Security:

10 Proposal for the Hatoyama Administration', The Tokyo Foundation Website, October 2009 , http://www.tokyofoundation.org /en/, consulted 9 May 2013.

\section{Others:}

Anonymous, 'Timeline: China Japan Island Dispute', Australia Network News - ABC News, 19 August 2012 , http://www.abc.net.au/news/201 2-08-19/an-japan-chinatimeline/4208770, consulted 21 June 2013.

Ministry of Defence, 'Japan's Annual White Paper 2011', Japan's Ministry of Defence Website, 2011, www.mod.go.jp/e/publ/w_paper 